\title{
COMPARING ENTREPRENEURIAL PASSION OF SOCIAL AND COMMERCIAL ENTREPRENEURS IN THE CZECH REPUBLIC
}

\section{Balgiashvili T.}

Social Entrepreneurship has become a buzzword due to the exponentially rising number of scientific works devoted to this topic. The prevalent part of the research focuses on the social side of the venture, while the other equally important entrepreneurial side is still in the shadows. Can it be that social entrepreneurs do not value the entrepreneurial aspect (inventing, founding and developing) of social entrepreneurship and are engaged in these activities merely because of other goals and passions (for example "helping", "social welfare" etc.)? This research conducted in Entrepreneurial passion, aims to identify the differences within the domain of inventing, founding and developing passion among social and commercial entrepreneurs. The paper also aims to find out if the cliche about the social cause being the only force that moves social entrepreneurs is right. The primary data was collected among 87 social and 119 commercial entrepreneurs. The Welch`s t-test and the Mann-Whitney-Wilcoxon test were applied. As a result, no statistically significant differences were found in any of the mentioned aspects (Inventing, founding and developing) of entrepreneurial passion of social and commercial entrepreneurs.

Keywords: Social Entrepreneurship; entrepreneurship; entrepreneurial passion JEL classification: M21, O35, D90

\section{Introduction}

The current research on social entrepreneurs states that he or she must have the same commitment and determination as traditional business entrepreneurs, and a deep passion for the social cause, minus an expectation of significant financial gains (Wiliams \& Nadin, 2011). That motivation for social entrepreneur is bound to different anticipants than those who engage themselves in the commercial ventures (Yitshaki \& Kropp, 2016).

For a number of authors (Austin et al., 2006; Dees, 2001; Dees \& Anderson, 2003; Venkataraman, 1997; Mair \& Marti, 2006) the social enterprise is a completely different and revolutionary way of doing business. This opinion is grounded with the findings of scholars Saul Estrin, Tomasz Mickiewicz and Ute Stephan (2016) who have proved that social entrepreneurship attracts those types of personalities, which would never go to the venture creation process otherwise. Moreover, the authors have articulated, that Entrepreneurial human capital is not so important for social ventures, as it is in case of commercial entities.

Probably because of these opinion-leaders, the current research disregards the entrepreneurial part of social venture, although there is also a number of researchers (Martin \& Osberg, 2007; Chambers, 2014; Meyskens et al., 2010) who believe entrepreneurship is the base for social venture. They even articulate that definition of "social entrepreneurship" must start with the word "entrepreneurship"- as the word "social" simply modifies it. 
Are social entrepreneurs passionate about producing and creating value? Or are the social entrepreneurs motivated to run the business just to solve the social problem, but are not happy with playing by free market rules? Are they passionate entrepreneurs together with their mission to help? Braga et al. (2014) identified passion as the source of motivation in both social and commercial venture. Although, this was not the main objective of the study, so the researchers could not study passion from a deeper perspective.

Evidence on whether social entrepreneurs also share the entrepreneurial drive for achievement and power (e.g. self-enhancement values, power and achievement motives) is more mixed. Generally, it is suggesting that social entrepreneurs score lower in this domain compared to their commercial counterparts. This in turn may hamper the growth and scaling of the ventures that they lead (Stephan \& Drencheva, 2017).

Social entrepreneurs want to leave a mark, to make a difference, and to be involved in activity that is meaningful and creates social value (Yitshaki \& Kropp, 2016). At the same time as being successful and creating sustainable impact, they also need to be passionate about creating and delivering values, creating effective business model and operations, and developing and supporting the growth of the entity (Dees \& Anderson, 2003). Our research wants to find out if passion for inventing, passion for founding, and passion for developing the venture are present in the "Passion orchestra" (a term first used by Huyghe et al., 2016, to express a set of different passions playing role in entrepreneurship), of social entrepreneurs. The research takes also a closer look how social and commercial ventures prioritize their goals.

The research stream (Austin et al., 2006; Williams \& Nadin, 2011) states that SEs (social entrepreneurs) and CEs (commercial entrepreneurs) both have mix of social and commercial goals and the only difference is the priorities given to each of them. We would like to find out if it is true for every entrepreneur and test the following hypothesis:

H1: There is a difference between the priorities given to Social and Economic goals between SEs and CEs founders.

Scholars who have been studying passion in social enterprises have excluded the entrepreneurial passion from being a social entrepreneur (Yitshaki \& Kropp, 2015; Williams \& Nadin, 2011). In the following research, we would like to find out:

H2a: CEs and SEs have the same level of passion for inventing.

$H 2 b$ : CEs and SEs have the same level of passion for founding the venture.

H2c: CEs and SEs have the same level of passion for developing the venture.

\section{Social Entrepreneurship}

Despite the recent increase in attention, social entrepreneurship is one of the least defined concepts in entrepreneurship and management research. Content analysis conducted on 567 articles concerning the topic of social entrepreneurship, retrieved from several bibliographic databases (EBSCO, ProQuest, and Google Scholar), has confirmed that there is no consistency in definitions and objects of focus (Cukier et al., 2011).

The image of social entrepreneurship as a preeminent moral actor further relies on the contention that the motives of social entrepreneurs are impeccable and noble, that social entrepreneurs can attain large-scale, systemic change (Cukier et al., 2011) and can 
lead towards a more ethical and socially inclusive capitalism (Dacin et al., 2011). P. Dey and C. Steyaert have moved emphasis off of ethics, as being a property or characteristic of the individual entrepreneur and moved towards ethics, that is practiced through social entrepreneur activities (Dey \& Steyaert, 2014). One of the main characteristics in social enterprises is dualism in their mission - it is entitled to follow both social and economic aims at the same time (Austin et al., 2006; Dees, 2001; Dees \& Anderson, 2003; Venkataraman, 1997; Mair \& Marti, 2006; Chambers, 2014; Meyskens et al., 2010). This causes the confusion in perception of SEs. Some easily assume social enterprise in part of non-profit sector can be financed with funds. Others are inclined to think it is the entity having the for-profit business model and devoting the part of the profit to improve the surroundings that created disarray (Grassl, 2012).

While economic sustainability is needed to pursue the social mission of social entrepreneurship initiatives, the creation of social value is the natural feature of the social venture, as the social entrepreneur's principal aim is to produce social change (Emerson, 2003). According OECD, social entrepreneurship creates the model, where "the economic value serves social objectives" (Emerson, 2003; OECD, 2010). Horsnell (2010) also agrees to the mentioned attitude with the notion, that "social enterprise is not balancing the double bottom lines of profit and social impact as though they are equally important". To this camp belongs also Makhlouf (2011) articulating that being profitable (or at least financially sustainable) for social entrepreneurs is the necessary means to the end: "Of course, there can be no social mission without money, but the first goal is mission" (Makhlouf, 2011).

Social entrepreneurial ventures are "the product of the social, cultural, commercial and political expectation of the innovation of the range of stakeholders, not sorely the vision of the social entrepreneur" (Newth, 2015). Scholars Colleen Robb and Jimmy Gandhi (2016) have proposed that social entrepreneurial ventures operate as system of systems - a collection of complex systems working together to achieve an overall outcome in line with its mission.

Social entrepreneurship can be an individual or collective (OECD, 2010), local and global cross sectoral phenomenon (Mair \& Ganly, 2010), that may shape both economic and social values and is capable to achieve both incremental and radical social transformation (OECD, 2010)).

\subsection{Social Entrepreneurship in the Czech Republic}

The entities that want to contribute to the public good, very often face with the market that does not appreciate their products or services. That is why they are forced to look for the alternative sources of finance. Obviously, the social enterprises which are trying to balance their economic and social goals are not as dependent on the public donations as non-profit organizations, but instead are discriminated in comparison with the commercial enterprises because of their wider scope (Vyskočil, 2014). As in case of non-profit organizations, market does not value all the activities that are in the scope of the social entrepreneurs (Dees \& Anderson, 2003).

Official statistics about social enterprises are scarce and limited in scope across the

whole Europe. The information is usually available on the number of legally recognized social enterprises (where these exist), but they do not cover the de-facto range of social 
enterprises, which in all countries comprises most of the social entrepreneurial 'population' (European Commission, 2015).

That is also true for Czech Republic - according to the only research that has been conducted on the socially oriented enterprises in Czech Republic has registered 225 entities that describe themselves as socially oriented. From 151 respondents reachable on the phone, $78(63 \%)$ is experiencing the problems in finance field (majority of them (52 $(42 \%))$ are not financially sustainable), 54 entities $(44 \%)$ are experiencing the lack of sales, and $41(33 \%)$ entities do not have neither the marketing communication strategy nor somebody who would take care of that. According to the same research the average turnover for the last 2 years (2014 and 2015) has been 4.515 mil. CZK (P3 - People, Planet, Profit, 2015). For comparison: after the financial crisis during 2010 the average turnover for the SMEs in Czech Republic was 24, 174 mill CZK (MPO, 2015). In fact, these statistics and figures cannot show the full picture as both social and economic value creation should be measured for SEs. One could argue that complications are mainly because of the hardly measurable social impact (Vidra et al., 2016), but financial impact measuring does not make less trouble as the traditional financial indicators used for CEs cannot capture the performance in SEs (Mouchamps, 2014).

\subsection{Entrepreneurial Passion}

Entrepreneurship is the embodiment of passion. It makes entrepreneurs believe in what they are doing, which is important for realizing their entrepreneurial dreams and achieving success against all odds (Ma \& Tan, 2006). According to Shane et al. (2003), passion can facilitate opportunity recognition, idea development, and opportunity execution (resource assembly, organizational design, market making, and product development).

Entrepreneurial passion plays a role in new venture formation and performance (Cardon et al., 2009), has a significant positive effect on venture capitalists' funding decisions (Chen et al., 2009). Passion has an indirect effect on venture growth (Smith et al., 2001) and enhances an entrepreneur's likelihood of success (Foo, 2011).

Existing research emphasizes that passion leads entrepreneurs to invest higher levels of energy and effort into new ventures and that entrepreneurial passion contributes to new venture success (Baum \& Locke, 2004), the opposite correlation was also observed - as resent research (Gielnik et al., 2017) states and higher entrepreneurial action is positively affecting the entrepreneurial passion.

Although the overall role of "being an entrepreneur" may be the object of passion (Murkiens et al., 2012), it is mostly analyzed considering the intense positive feelings and identity centrality towards tasks and activities fitting to entrepreneurship. Cardon et al. (2012) suggested the more detailed approach focused on three roles that entrepreneurs may experience differently, but are consistently found at the heart of the entrepreneurial process: 1) inventing new products or services, 2) founding new organizations, and 3) developing these organizations beyond their initial survival and successes (Cardon et al., 2009).

Each of these roles involves distinct sets of tasks and activities, reflecting the challenges associated with different aspects of the entrepreneurial process (Gundry \& Welsch, 2001; Katila \& Ahuja, 2002). This tool neither focuses on broad idea of entrepreneurship, nor involves the distinctive details of venture, products \& services, 
industry or markets and that is why can be applied in cross-sectoral research (Cardon et al., 2012).

Passion for inventing involves looking for a new market opportunity, developing new products or services, and working with new prototypes (Cardon et al., 2009). The key changes of the economic or social landscape require invention (Drucker, 1985). Some entrepreneurs search for innovative ideas deeper and more frequently than others (Katila \& Ahuja, 2002).

Passion for founding relates to assembling the necessary financial, human, and social resources needed to create a new venture (Cardon et al., 2009). According to Aldrich and Zimmer (1986) the desire to launch an organization is an important motivator for many entrepreneurs. Entrepreneurs who experience passion for founding primarily enjoy the process of founding a venture, and often develop identities that are intertwined with the venture identity (Cardon et al., 2005).

Passion for developing is associated with the growth and expansion of the venture after founding. These individuals often exhibit different strategies for organizational management than their counterparts (Gundry \& Welsch, 2001). They also tend to communicate with key stakeholders in a manner that promotes the organization's continued expansion (Baum \& Locke, 2004). Entrepreneurs who experience passion for developing their firm(s) may enjoy activities such as increasing sales, hiring new employees, or finding external investors to fund such developments (Baum \& Locke, 2004).

\section{Research Design}

The first widely used scale measuring passion was developed by Vallerand et al. (2003). It was popular because its universality and easy application. After almost a decade a team of scholars including M. Cardon, D. Gregoire and C. Stevens came with the scale specially constructed and validated for entrepreneurial passion (Cardon et al., 2012). The results of this study indicate high reliability (Hair et al., 2006) and were later validated by several other studies (Tasnim \& Singh, 2016; Kerrick et al., 2016). The scale delineated Entrepreneurial passion as a construct encompassing three domains: inventing, founding, and developing (see Table 3).

\subsection{Methodology}

We have applied the questionnaire created and validated by Cardon et al. (2012) to find out more about the levels of entrepreneurial passion that the social entrepreneurs have in comparison with their commercial counterparts. The translation to Czech language has been validated by native speakers (Appendix 1). We added 1 question to the main questionnaire tool - to identify the founder's priorities given to financial and social outcomes on the entrepreneurial venture.

Likert scale has been applied to register the replies to the questionnaire. This scale was developed in 1932 by R. Likert to measure attitudes (Likert, 1932). The typical Likert scale is a 5- or 7-point ordinal scale used by respondents to rate the degree to which they agree or disagree with a statement. We used 7-point scale according to the recommendation of the authors (Cardon et al., 2012). 


\subsection{Sample}

The database was created with the responses obtained from both social and commercial entrepreneurs separately. The on-line questionnaire was sent to 253 subjects. The majority of them (205 subjects) were identified in an online database created by the platform Czech Social Entrepreneurship - "České sociální podnikání" (2017). The rest of the 48 subjects were found through the various platforms, such as accelerators, incubators, competitions etc. Eighty-seven replies were obtained. On the other hand, the same questionnaire was send to 2600 commercial entrepreneurs, that were identified with the Albertina database (search criteria - founded after 2006, under 24 employees, and limited with activity types that according to the $3 \mathrm{P}$ report were most frequent profile of social enterprises in Czech Republic (different types of services and maintenance, manufacturing, food, accommodation and tourism)). In the end, 119 results were obtained.

\subsection{Statistics}

For analyzing the results obtained through the Likert scale, it is recommended to use the Welch's t-test and Mann-Whitney-Wilcoxon test (Winter \& Dodou, 2012). Welch's t-test or unequal variances t-test is a two-sample test that is used to test the hypothesis about two populations having equal means (Welch, 1947). It is designed for unequal variances, but the assumption of normality is maintained (Welch, 1947). Scholars state this test can handle unequal sample sizes (Ruxton, 2006)

Mann-Whitney-Wilcoxon test is testing the hypothesis, that it is equally likely that a randomly selected value from one sample will be less than or greater than a randomly selected value from a second sample (Fay \& Proschan, 2017). As non-parametric test, it does not require the normality of the data, but does need the assumption about the equal variances to be fulfilled in case the analyzed samples are not equal (Fay \& Proschan, 2017).

To be able to assume obtained observations fulfill the preconditions for both tests, we conducted Pearson`s Chi-square to test the normality of data (Chernick, 2012) and F test for comparing the variances in both samples (Rees, 2001).

Pearson's chi-squared test $(\chi 2)$ is a statistical test applied to sets of categorical data to test a null hypothesis stating that the frequency distribution of certain events observed in a sample is consistent with a theoretical distribution (Pearson, 1900).

Pearson`s chi-square test has the following assumptions (Pearson, 1900; Yates et al., 1999):

- Each observation is independent of all the others (i.e., one observation per subject);

- No more than $20 \%$ of the expected counts are less than 5 and all individual expected counts are 1 or greater.

The sample consists of the multiple observations from the same respondents, but the observations for each type of passion were tested separately. The assumption about independency is fulfilled. The second assumption is also attained as the observations per group (SE, CE) are bigger than 5 while testing all 4 hypotheses.

After considering the results of the Chi-square test (Table 1) the observations obtained can be considered as of normal distribution (the hypothesis that the data do follow the normal distribution was confirmed). 
Table 1 | Results of Pearson`s Chi-Square goodness of fit test

\begin{tabular}{|l|c|c|}
\hline Chi-square test & $\mathbf{X}^{2}$ value & $\mathbf{p}$-value \\
\hline Passion for innovating & 12.33 & 0.2896 \\
\hline Passion for foundation & 20.559 & 0.6646 \\
\hline Passion for development & 9.7039 & 0.9156 \\
\hline
\end{tabular}

Source: Own analysis conducted in $\mathrm{R}$

To find out if the variances are equal in between the tested samples $\left(\sigma^{2}{ }_{1}=\sigma^{2}{ }_{2}\right), \mathrm{F}$ - test was suggested (Rees, 2001). Data normality (Markowski \& Markowski, 1990) has been verified by the Chi-Square test (Table 1 ).

F test compared the data variance between the sample 1 (Social Entrepreneurs, $n=87$ ) and sample 2 (commercial entrepreneurs, $n=119)$. The H0 hypothesis $\left(\sigma_{\mathrm{SE}}^{2}=\sigma_{\mathrm{CE}}^{2}\right)$ was tested. F test could not reject the $\mathrm{H} 0$ hypothesis that the difference between the sample's variances is zero (Table 2).

Table 2 | Results of the F test

\begin{tabular}{|l|c|c|c|}
\hline $\begin{array}{l}\text { F test for comparing variances between } \\
\text { SEs and CEs }\end{array}$ & F statistics & $\begin{array}{c}\text { 95\% confidence } \\
\text { interval }\end{array}$ & P value \\
\hline Passion for innovating & 0.919 & $(0.619,1.378)$ & 0.686 \\
\hline Passion for founding & 1.015 & $(0.684,1.522)$ & 0.935 \\
\hline Passion for developing & 0.925 & $(0.623,1.386)$ & 0.708 \\
\hline
\end{tabular}

Source: Own analysis conducted in $\mathrm{R}$

The hypothesis about the data normality could not be rejected as well as the hypothesis about the variances being the same. As a result, the statistical analysis was conducted using both parametric (Welch's t-test) and non-parametric (MWW) test (Table 4).

\section{Results}

As a first step, the preliminary explorative analysis has been conducted in order to get the general overview of the collected data (Table 3). In the first column, there are codes helping to identify which type of passion is referred by the statement. There are the original statements in the second column. The columns "SE mean" and "CE mean" express the mean for social and commercial ventures respectively. The same applies for "SE SD" and "CE SD", where "SD" stands for the standard deviation. In the last two columns, the differences are displayed. In most cases, means for social entrepreneurs are less that means for their commercial counterparts. We also explored how significant these differences are from the statistical perspective (Table 4). 
Table 3 | Results of the exploratory analysis

\begin{tabular}{|c|c|c|c|c|c|c|c|}
\hline ID & Statement & SE mean & SE SD & CE mean & CE SD & $\Delta$ mean & $\Delta \mathrm{SD}$ \\
\hline Inv1 & $\begin{array}{l}\text { It is exciting to figure out new } \\
\text { ways to solve unmet market } \\
\text { needs that can be served. }\end{array}$ & 5.11 & 1.57 & 5.67 & 1.47 & -0.55 & 0.11 \\
\hline Inv2 & $\begin{array}{l}\text { Searching for new ideas for } \\
\text { products/services to offer is } \\
\text { enjoyable to me }\end{array}$ & 5.94 & 1.38 & 6.04 & 1.40 & -0.10 & -0.01 \\
\hline Inv3 & $\begin{array}{l}\text { I am motivated to figure } \\
\text { out how to make existing } \\
\text { products/services better }\end{array}$ & 6.15 & 1.16 & 6.17 & 1.18 & -0.02 & -0.03 \\
\hline Inv4 & $\begin{array}{l}\text { Scanning the environment } \\
\text { for new opportunities really } \\
\text { excites me }\end{array}$ & 5.06 & 1.64 & 5.14 & 1.61 & -0.08 & 0.04 \\
\hline Fnd1 & $\begin{array}{l}\text { Inventing new solutions to } \\
\text { problems is an important part } \\
\text { of who I am }\end{array}$ & 6.16 & 1.20 & 6.01 & 1.29 & 0.15 & -0.09 \\
\hline Fnd2 & $\begin{array}{l}\text { Establishing a new company } \\
\text { excites me }\end{array}$ & 4.55 & 1.96 & 5.06 & 1.89 & -0.51 & 0.07 \\
\hline Fnd3 & $\begin{array}{l}\text { Owning my own company } \\
\text { energizes me }\end{array}$ & 4.91 & 1.74 & 5.30 & 1.69 & -0.39 & 0.05 \\
\hline Fnd4 & $\begin{array}{l}\text { Nurturing a new business } \\
\text { through its emerging success } \\
\text { is enjoyable }\end{array}$ & 5.68 & 1.50 & 5.74 & 1.39 & -0.06 & 0.11 \\
\hline Fnd5 & $\begin{array}{l}\text { Being the founder of } \\
\text { a business is an important } \\
\text { part of who I am }\end{array}$ & 5.31 & 1.77 & 5.51 & 1.64 & -0.20 & 0.13 \\
\hline Dev1 & $\begin{array}{l}\text { I really like finding the } \\
\text { right people to market my } \\
\text { products/services to }\end{array}$ & 5.62 & 1.52 & 5.55 & 1.52 & 0.07 & 0.00 \\
\hline Dev2 & $\begin{array}{l}\text { Assembling the right people } \\
\text { to work is exciting }\end{array}$ & 5.39 & 1.79 & 5.17 & 1.85 & 0.22 & -0.06 \\
\hline Dev3 & $\begin{array}{l}\text { Pushing my employees and } \\
\text { myself to make our company } \\
\text { better motivates me }\end{array}$ & 5.89 & 1.24 & 5.72 & 1.33 & 0.16 & -0.09 \\
\hline Dev4 & $\begin{array}{l}\text { Nurturing and growing } \\
\text { companies is an important } \\
\text { part of who I am }\end{array}$ & 5.69 & 1.42 & 5.77 & 1.38 & -0.08 & 0.04 \\
\hline
\end{tabular}

Source: own calculations based on the obtained data 


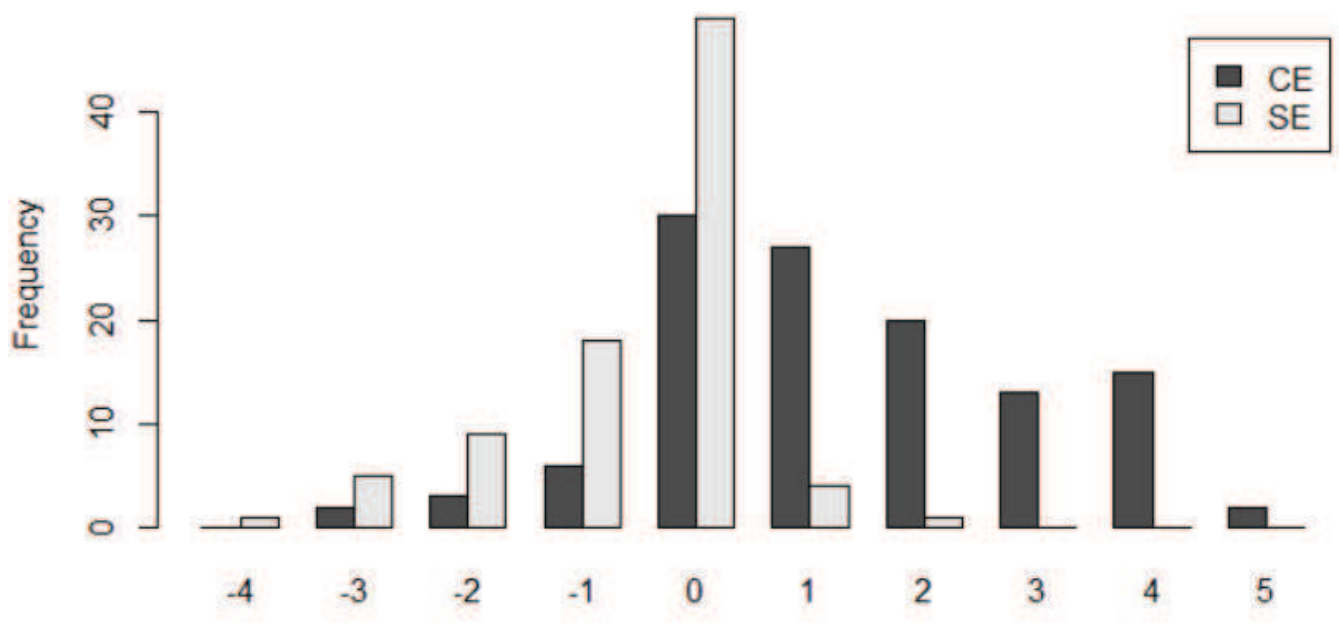

priority given to commercial goals in comparison with social goals

Source: Own analysis conducted in $\mathrm{R}$

The first tested hypothesis is:

H1: The difference between the priorities given to Social and Economic goals in statistically insignificant between SES and CES.

We asked our respondents to prioritize the social and financial goals. As we anticipated before, our findings are in accordance with the dozens of other researchers, stating that social and commercial entrepreneurs differ according to their priorities given to these groups of goals. The MWW test has been conducted on the differences between the priorities given to the commercial goals compared with social (for example if the respondent marked the commercial goal with 7 and social with 5 , the difference is 2 points). P-value for this test is less than 0.01 (Table 4), so the null hypothesis about having no difference between social and commercial ventures goal orientation was rejected at the 0.01 confidence level. The difference was statistically significant.

The other 3 hypotheses are stated below:

H2a: CEs and SEs have the same level of passion for inventing.

H2c: CEs and SEs have the same level of passion for developing the venture.

$H 2 b$ : CEs and SEs have the same level of passion for founding the venture.

In case of H2a, P-value for the MWW is 0.1428 and 0.2541 for the t-test (Table 4), which makes it clear we cannot reject the null hypothesis about social and commercial entrepreneurs having the same level of passion for inventing with even at the 0.1 confidence level. On the boxplot (Figure 2) the outliers can be seen, but they are not significant to influence the results of the analysis. In case of research statement $\mathrm{H} 2 \mathrm{~b}$, the statistical tests also do not highlight the statistically significant difference between the SEs and CEs neither between the levels of passion for founding the venture. For MWW test, the P-value is 0.1596. The result of Welch t-test is more decisive with the P-value 0.1766 (Table 4). In the end, both tests confirm that the null hypothesis cannot be rejected. 
Table 4 | Summary of statistical analysis

\begin{tabular}{|l|c|c|c|c|c|c|}
\hline $\begin{array}{c}\text { Hypothesis } \\
\left(\mathbf{n}_{\mathbf{1}}=\mathbf{8 7},\right. \\
\mathbf{n}_{\mathbf{2}}=\mathbf{1 1 9 )}\end{array}$ & $\begin{array}{c}\text { MWW } \\
\text { P-value }\end{array}$ & MWW w & $\begin{array}{c}\text { t test } \\
\text { P-value }\end{array}$ & t-test t & Mean CE & Mean SE \\
\hline H1 & $2.2 \mathrm{e}-16^{* * *}$ & 8515.5 & N/A & N/A & N/A & N/A \\
\hline H2a & 0.1428 & 5793.5 & 0.2541 & 1.1439 & 5.75000 & 5.5661 \\
\hline H2b & 0.1596 & 5770.0 & 0.1766 & 1.3567 & 5.5388 & 5.3218 \\
\hline H2c & 0.6216 & 4968.5 & 0.6514 & -0.4526 & 5.5714 & 5.6466 \\
\hline
\end{tabular}

Note:* - significant at $0.1,{ }^{* *}$ - significant at $0.05,{ }^{* * *}$ - significant at 0.01

Source: Own analysis conducted in $\mathrm{R}$

The MWW test does not highlight the statistically significant difference between the SEs and CEs, neither in terms of levels of passion for developing the venture (research statement $\mathrm{H} 2 \mathrm{c}$ ). For MWW. P-value is 0.6216 (that is much higher than the 0.05 confidence level and therefore we cannot reject the null hypothesis). The Welch test has approximately the same result with the p-value 0.6514 (Table 4). In the end, both tests failed to reject the null hypothesis.

Figure 2 | Boxplot for passion for inventing, founding, developing for SEs and CEs
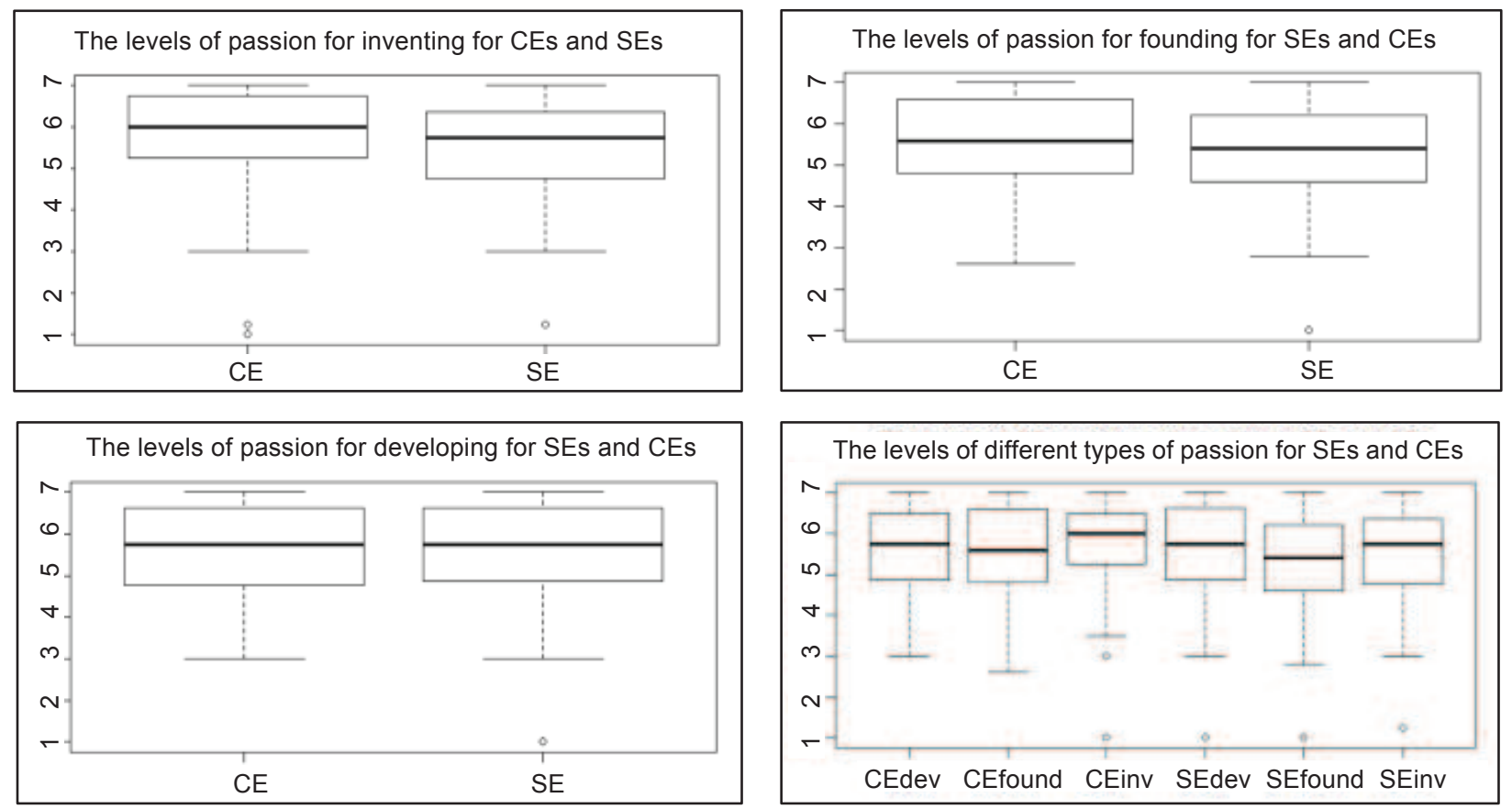

Note: Created based on the research results for passion for inventing, founding, developing for SEs and CEs. The right down boxplot is for all measured types of passion for SEs and CEs.

Source: Own analysis conducted in $\mathrm{R}$ 


\section{Discussion}

In the first part of the research, the results regarding the tested hypothesis H1 highlight the statistical difference between the groups of social and commercial entrepreneurship. This aligns with the previous research ( 2 above). During the analysis, one fact attracted our attention - 36 out of 119 respondents, from the pool of commercial entrepreneurs, either gave the social impact goal the higher priority than to the commercial goal, or they gave the same $(5,6,7)$ amount of points. On the other hand, 5 out of 87 respondents from the pool of social entrepreneurs put the commercial goal on higher priority than the social impact. This fact clearly shows that 1 . There is no clear line between the commercial and social entrepreneurship and 2. Not all social entrepreneurs are keener on their social goals than on financial figures and all the way around. For details please see the Figure 2.

Our findings align with the scholars, who state that the boarders between the social and commercial entrepreneurship are blurred (Chambers, 2014). The theory is describing only extremes that are rare and state that distinction is not relevant as most of the enterprises do not follow pure social or economic goals (Austin et al., 2003; Williams \& Nadin, 2011).

The second part of our research was devoted to comparing the levels of Entrepreneurial passion for inventing, founding and developing the venture in between social and commercial entrepreneurs. The hypothesis $\mathrm{H} 2 \mathrm{a}$ regarding the same levels of passion for inventing in SEs and CEs, could not be rejected. It enhances the opinion that social entrepreneurs are not significantly distinguished from their commercial counterparts in actively seeking out the new opportunities, coming up with new product or service ideas, and inventing new solutions to important needs and problems.

For the hypothesis $\mathrm{H} 2 \mathrm{~b}$ regarding the same levels of passion for founding the venture in CEs and SEs, the null hypothesis could not be rejected either. According to the findings, social entrepreneurs experience the same levels of passion for assembling the necessary financial, human, and social resources needed to create a new venture (Cardon et al., 2009) as their commercial counterparts.

The answer on the research question H2c. is also positive. What does that mean? Social entrepreneurs love to devote their energy to growing and expanding his or her ventures with the same levels of passion as founders of commercial ventures. The entrepreneurs also exhibit different organizational strategies and management styles for growth and communicate with key stakeholder in a way that promotes the organization's continued expansion (Baum \& Locke, 2004). As a result, we can articulate that, that social entrepreneurs may enjoy activities such as increasing sales, hiring new employees, or finding external investors to fund such developments on the same level as their commercial counterparts.

The possible limitations could be the number of the respondents. It was enough for the statistical test validity, but still the study would benefit from higher engagement levels. The study could be also biased because the research is based on self-report and the answers can be easily influenced by one's desire to appear better even if the questionnaire was anonymous.

As entrepreneurial identity is shaped by a process rooted in an entrepreneur's past personal and occupational experiences (Yitshaki \& Kropp, 2016) and it is 'crafted and re-crafted over time' (Giddens, 1991), Entrepreneurial passion can be also influenced by different social and demographical characteristics of the sample. 


\section{Conclusion}

In the theoretical part, the concept of social entrepreneurship was discussed with all its complexity. After describing the current situation of social entrepreneurship in the Czech Republic the paper led to the issue of entrepreneurial passion and formulates the questions for this research.

As a research tool, we adopted the questionnaire suggested by Cardon et al. (2012) that examines the passion for inventing, passion for founding and passion for developing. We used both parametric (Welch two sample t-test) and non-parametric (Mann-Whitney-Wilcoxon) tests according to the recommendations of Winter and Dodou (2012).

The statistical analysis of the 87 replies from the social and 119 replies from the commercial entrepreneurs suggests that:

1. SEs and CEs give different priorities to the social and commercial goals, but fail to prove that this rule draws a bold line in between those two (the eloquent number of respondents did not align to this rule.

2. Social and commercial entrepreneurs both possess three tested components of entrepreneurial passion. The study didn't prove statistically significant difference between these 2 pools of respondents.

The research pioneered and proved that passion for inventing, passion for founding and passion for developing the venture are represented in the "Passion orchestra" of social entrepreneurs as their commercial counterparts. We also proved that social entrepreneurs (SEs) and commercial entrepreneurs (CEs) give different priorities to the social and commercial goals, but this rule fails to create a sharp distinction between those two. To sum up, the paper undermines the cliché that believes the social cause is the only force that moves social entrepreneurs. In fact, the paper finds out that social entrepreneurs are passionate entrepreneurs alongside solving the urgent social and environmental problems.

The research could be interesting for the following groups of stakeholders:

- Different incubators and accelerators concerned with social entrepreneurs and their ventures;

- Governmental and non-governmental bodies supporting social entrepreneurship,

- Funds oriented supporting the social ventures,

- Academic researchers,

- Public with the interest towards the social entrepreneurship;

All in all, findings are believed to enrich the research in the field of social ventures and entrepreneurship in Czech Republic and serve as a pillar for the researchers who decide to devote themselves to this topic. Possible directions for the future research could be:

- Study the levels different types of the passion (inventing, founding and developing) in Social entrepreneurs to find out what type of passion is prevalent while taking up and leading the venture,

- Conduct the same research on the bigger sample of respondents,

- Conduct the same research in the international context to identify any differences if they exist. 


\section{References}

Aldrich, H. E., \& Zimmer, C. (1986). Entrepreneurship through social networks. In D. L. Sexton, \& R. Smilor (Eds.), The Art and Science of Entrepreneurship (pp. 3-23). Cambridge, MA: Ballinger.

Austin, J., Stevenson, H., \& Wei-Skillern, J. (2006). Social entrepreneurship and commercial entrepreneurship: Same, Different or both? Working paper series no. 04-029.

Baum, J. R., \& Locke, E. A. (2004). The relationship of entrepreneurial traits, skill, and motivation to subsequent venture growth. Journal of Applied Psychology, 89, 587-598.

Braga, J. C., Proenca, T., \& Ferreira, M. R. (2014). Motivations for social entrepreneurshipEvidences from Portugal. Tékhne, 12, 11-21.

Cardon, M. S., Gregoire, D. A., Stevens, C. E., \& Patel, P. C. (2013). Measuring entrepreneurial passion: Conceptual foundations and scale validation. Journal of Business Venturing, 28(3), 373-396.

Cardon, M. S., Wincent, J., Singh, J., \& Drnovsek, M. (2009). The nature and experience of entrepreneurial passion. Academy of management Review, 34(3), 511-532.

Cardon, M., Sudek, R., \& Mitteness, C. (2009). The impact of perceived entrepreneurial passion on angel investing. In A. Zacharakis (Ed.), Frontiers of Entrepreneurship Research: Proceedings of the Babson College Entrepreneurship Research Conference, Vol 29. Wellesley, MA.

Cardon, M. S., Zietsma, C., Saparito, P., Matherne, B. P., \& Davis, C. (2005). A tale of passion: New insights into entrepreneurship from a parenthood metaphor. Journal of Business Venturing, 20(1), 23-45.

České Sociální Podnikání. (2017). Directory of Social Entreprises. Retrieved May 17, 2017 from http://www.ceske-socialni-podnikani.cz/en/adresar-socialnich-podniku.

Chambers, L. (2014). Growing a hybrid venture: Toward a theory of mission drift in social entrepreneurship. St. Gallen: University of St. Gallen.

Chen, X. P., Yao, X., \& Kotha, S. (2009). Entrepreneur passion and preparedness in business plan presentations: a persuasion analysis of venture capitalists' funding decisions. Academy of Management Journal, 52(1), 199-214.

Chernick, M. (2012). How should one interpret the comparison of means from different sample sizes? Retrieved June 29, 2017 from https://stats.stackexchange.com/questions/31326/ how-should-one-interpret-the-comparison-of-means-from-different-samplesizes/31330\#31330.

Cukier, W., Trenholm, S., \& Gekas, D. C. (2011). Social Entrepreneurship: A Content Analysis. Journal of Strategic Innovation and Sustainability, 7(1), 99-119.

Dacin, M. T., Dacin, P. A., \& Tracey, P. (2011). Social entrepreneurship: A critique and future directions. Organization Science, 22(5), 1203-1213.

Dees, J. G. (2001). The meaning of "social entrepreneruship". Center for the advancement of social entrepreneurship, Fuqua School of Business, Duke University.

Dees, J. G., \& Anderson, B. B. (2003). For Profit Social Ventures. In M. L. Kourilsky, \& W. B. Walstad (Eds.), Social Entrepreneurship. Senate Hall Academic Publishing.

Dey, P., \& Steyaert, C. (2016). Rethinking the space of ethics in social entrepreneurship: Power, subjectivity, and practices of freedom. Journal of Business Ethics, 133(4), 627-641.

Drucker, P. F. (1985). Innovation and Entrepreneurship: Practices and Principles. New York: Harper \& Row. 
Emerson, J. (2003). The blended value map: Tracking the interests and opportunities of economic, social and environmental values creation. Retrieved January 17, 2017 from https://www.hewlett.org/wp-content/uploads/2016/08/BlendedValueMapFinal.pdf.

Estrin, S., Mickiewicz, T., \& Stephan, U. (2016). Human capital in social and commercial entrepreneurship. Journal of Business Venturing, 31(4), 449-467.

European Commision (2015). A map of social entreprises and their eco-systems in Europe - Synthesis Report. Brussels: Directorate-General for Employment, Social Affairs and Inclusion.

Fay, M. P., \& Proschan, M. A. (2010). Wilcoxon-Mann-Whitney or t-test? On assumptions for hypothesis tests and multiple interpretations of decision rules. Statistics Surveys, 4, 1-39.

Foo, M. D. (2011). Emotions and entrepreneurial opportunity evaluation. Entrepreneurship Theory and Practice, 35(2), 375-393.

Giddens, A. (1991). Modernity and Self Identity: Self and Society in the Late Modern Age. Cambridge: Polity Press.

Gielnik, M. M., Uy, M. A., Funken, R., \& Bischoff, K. M. (2017). Boosting and sustaining passion: A long-term perspective on the effects of entrepreneurship training. Journal of Business Venturing, 32(3), 334-353.

Grassl, W. (2012). Business models of social enterprise: A design approach to hybridity. ACRN Journal of Entrepreneurship Perspectives, 1(1), 37-60.

Gundry, L. K., \& Welsch, H. P. (2001). The ambitious entrepreneur: High growth strategies of women-owned enterprises. Journal of Business Venturing, 16(5), 453-470.

Hair, J., Black, W., Babin, B., Anderson, R., \& Tatham, B. (2006). Multivariante data Analysis (6th ed.). Upper Saddle River, NJ: Pearson.

Horsnell, A. (2010). Social Entrepreneurship- Social Enterprise. Retrieved May 20, 2017 from http://Managementhelp.Org/soc_entr/soc.entr.htm

Huyghe, A., Knockaert, M., \& Obschonka, M. (2016). Unraveling the "passion orchestra" in academia. Journal of Business Venturing, 31(3), 344-364.

Katila, R., \& Ahuja, G. (2002). Something old, something new: A longitudinal study of search behavior and new product introduction. Academy of Management Journal, 45(6), 1183-1194.

Kerrick, S. A., Cumberland, D., \& Choi, N. (2016). Comparing military veterans and civilians responses to an entrepreneurship education program. Jounral of Entrepreneurship Education, 19(1), 9-23.

Likert, R. (1932). A technique for the measurement of attitudes. Archives of Psychology 22(140), 55.

Ma, H., \& Tan, T. (2006). Key components and implications of entrepreneurship and small business. Journal of Small Business Management, 44(3), 704-725.

Mair, J., \& Ganly, K. (2010). Social entrepreneurship: innovating towards sustainability. In E. Assadourian. (Ed.), State of World 2010: Transforming Cultures from Consumerism to Sustainability (pp. 103-109). Washington DC: The World watch Institute.

Mair, J., \& Marti, J. (2006). Social Entrepreneurship research: a source of explanation, prediciton and delight. Working Papers, IESE Business School, Universoty of Navarra.

Makhlouf, H. H. (2011). Social Entrepreneurship: Generating Solutions to Global Challenges. International Journal of Management and Information Systems, 15(1), 1-8.

Markowski, C. A., \& Markowski, E. P. (1990). Conditions for the effectiveness of a preliminary test of variance. The American Statistician, 44(4), 322-326. 
Martin, R. L., \& Osberg, S. (2007). Social entrepreneurship: The case for definition. Stanford social Innovation Review, 5(2), 28-39.

Meyskens, M., Robb-Post, C., Stamp, J. A., Carsrud, A. L., \& Reynolds, P. D. (2010). Social ventures from a Resource-Based perspective: An exploratory study assessing global Ashoka fellows. Entrepreneurship Theory and Practice, 34(4), 661-680.

Mouchamps, H. (2014). Weighing elephants with kitchen scales: The relevance of traditional performance measurement tools for social enterprises. International Journal of Productivity and Performance Management, 63(6), 727-745.

MPO (2015). Zpráva o vývoji malého a středního podnikání a jeho podpoře v roce 2015. Prague: Ministry of Industry and Trade.

Murnieks, C. Y., Mosakowski, E., \& Cardon, M. S. (2014). Pathways of passion: Identity centrality, passion, and behavior among entrepreneurs. Journal of Management, 40(6), 1583-1606.

Newth, J. (2016). Social enterprise innovation in context: Stakeholder influence through contestation. Entrepreneurship Research Journal, 6(4), 369-399.

OECD. (2010). Chapter 5; Social Entrepreneruship and Social Innovation. In SMEs, Entrepreneurship and Innovation (pp. 185 - 215). Organization for Economic Co-operation and Development.

Pearson, K. (1900). X. On the criterion that a given system of deviations from the probable in the case of a correlated system of variables is such that it can be reasonably supposed to have arisen from random sampling. The London, Edinburgh, and Dublin Philosophical Magazine and Journal of Science, 50(302), 157-175.

P3 - People, Planet, Profit (2015). Vyhodnocení dotazníkového šetření sociálních podniků v ČR. Retrieved November 20, 2017 from http://www.ceske-socialni-podnikani.cz/images/ pdf/Socialni_podniky_setreni_2015.pdf.

Rees, D. (2001). Essential Statistics (4th ed.). CRC Press.

Robb, C., \& Gandhi, S. J. (2016). Social Entrepreneurial Ventures: On the Edge of Chaos? Entrepreneurial Research Journal, 6(1), 111-133.

Ruxton, G. D. (2006). The unequal variance t-test is an underused alternative to Student's t-test and the Mann-Whitney U test. Behavioral Ecology, 17(4), 688-690.

Shane, S., Locke, E. A., \& Collins, C. J. (2003). Entrepreneurial motivation. Human Resource Management Review, 13(2), 257-279.

Smith, K. G., Locke, E. A., \& Baum, J. R. (2001). A Multi-Dimensional Model of Venture Growth. Academy of Management Journal, 44(2), 292-303.

Stephan, U. \&. (2017). The person in social entrepreneurship: A systematic review of research on the social entrepreneurial personality. In G. Ahmetoglu, T. Chamorro-Premuzic, B. Klinger, \& T. Karcisky (Eds.), The Wiley Handbook of Entrepreneurship (pp. 205-230). Chichester: John Wiley.

Tasnim, R., \& Singh, H. (2016). What, exactly, is Entrepreneurial Commitment? Modeling the Commitment of Successful Entrepreneurs. Journal of Applied Management and Entrepreneurship, 21(3), 6-35.

Vallerand, R. J., Blanchard, C., Mageau, G. A., Koestner, R., Ratelle, C., Léonard, M., ... \& Marsolais, J. (2003). Les passions de l'ame: on obsessive and harmonious passion. Journal of personality and social psychology, 85(4), 756.

Venkataraman, S. (1997). The distinctive domain of entrepreneurship research. Advances in Entrepreneurship, Firm Emergence and Growth, 3(1), 119-138. 
Vidra, R., Klinger, Florman, M., \& Facada, M. j. (2016). A critical evaluation of social impact assessment methods. London: LSE Enterprise Working Paper \#1602.

Vyskočil, I. M. (2014). Podklad pro koncepci politiky vlády vůči NNO ro roku 2020. CVNS Centrum pro výzkům neziskového sektoru. Faculty of Economics and Administration, Masaryk University in Brno.

Welch, B. L. (1947). The generalization of "Student's" problem when several different population variances are involved. Biometrika. 34 (1-2), 28-35.

Williams, C. C., \& Nadin, S. (2011). Beyond the commercial versus social entrepreneurship divide: Some lessons from English localities. Social Enterprise Journal, 7(2), 118-129.

Winter, J. C., \& Dodou, D. (2012). Five-point Likert Items: t test versus Mann-WhitneyWilcoxon. Practical Assessment, Research \& Evaluation, 15(11), 1-16.

Yates D., Moore D. S., \& McCabe, G. P. (1999). The Practice of Statistics. New York: W. H. Freeman.

Yitshaki, R., \& Kropp, F. (2016). Entrepreneurial passions and identities in different contexts: a comparison between high-tech and social entrepreneurs. Entrepreneurship \& Regional Development, 28(3-4), 206-233.

Yitshaki, R., \& Kropp, F. (2016). Motivations and opportunity recognition of social entrepreneurs. Journal of Small Business Management, 54(2), 546-565.

\section{Author}

\section{Tamar Balgiashvili}

Faculty of Business Administration

University of Economics, Prague

Prague nam. W. Churchilla 4, 130 67, Prague 3

Czech Republic

xbalt10@vse.cz 


\section{Appendix 1}

Attachment 1 Translation of the research questionnaire from English (original) to Czech (Cardon, Gregoire, Stevens, \& Patel, 2012)

\begin{tabular}{|c|c|c|}
\hline & English version & Czech Version \\
\hline Inv1 & $\begin{array}{l}\text { It is exciting to figure out new ways to solve } \\
\text { unmet market needs that can be served. }\end{array}$ & $\begin{array}{l}\text { Je vzrušující objevovat nové způsoby, jak } \\
\text { vydělat na neuspokojených potřebách trhu }\end{array}$ \\
\hline Inv2 & $\begin{array}{l}\text { Searching for new ideas for products/ } \\
\text { services to offer is enjoyable to me }\end{array}$ & $\begin{array}{l}\text { Baví mě hledat nové nápady na produkty či } \\
\text { služeb, které je možné nabídnout }\end{array}$ \\
\hline Inv3 & $\begin{array}{l}\text { I am motivated to figure out how to make } \\
\text { existing products/services better }\end{array}$ & $\begin{array}{l}\text { Motivuje mě hledat způsoby, jak zlepšit } \\
\text { stávající produkty či služby }\end{array}$ \\
\hline Inv4 & $\begin{array}{l}\text { Scanning the environment for new } \\
\text { opportunities really excites me }\end{array}$ & $\begin{array}{l}\text { Velmi mě naplňuje analyzovat tržní } \\
\text { prostředí a hledat nové př́ležitosti. }\end{array}$ \\
\hline Fnd1 & $\begin{array}{l}\text { Inventing new solutions to problems is an } \\
\text { important part of whol am }\end{array}$ & $\begin{array}{l}\text { Vymýšlení nových řešení je důležitou } \\
\text { součásti toho, kým jsem. }\end{array}$ \\
\hline Fnd2 & Establishing a new company excites me & $\begin{array}{l}\text { Jsem nadšený při zakládání nové } \\
\text { společnosti }\end{array}$ \\
\hline Fnd3 & Owning my own company energizes me & Vlastnictví mojí společnosti mne nabíjí \\
\hline Fnd4 & $\begin{array}{l}\text { Nurturing a new business through its } \\
\text { emerging success is enjoyable }\end{array}$ & $\begin{array}{l}\text { Baví mě pečovat o novou společnost skrz } \\
\text { její postupně vznikající úspěch }\end{array}$ \\
\hline Fnd5 & $\begin{array}{l}\text { Being the founder of a business is an } \\
\text { important part of who l am }\end{array}$ & $\begin{array}{l}\text { Být zakladatelem společnosti je důležitou } \\
\text { součástí toho, kým jsem. }\end{array}$ \\
\hline Dev1 & $\begin{array}{l}\text { I really like finding the right people to } \\
\text { market my products/services to }\end{array}$ & $\begin{array}{l}\text { Opravdu mě baví nacházet ty správné lidi, } \\
\text { kterým mohu poskytovat své produkty } \\
\text { a služby. }\end{array}$ \\
\hline Dev2 & $\begin{array}{l}\text { Assembling the right people to work is } \\
\text { exciting }\end{array}$ & $\begin{array}{l}\text { Je pro mne vzrušující nacházet a získávat } \\
\text { do týmu ty správné lidi. }\end{array}$ \\
\hline Dev3 & $\begin{array}{l}\text { Pushing my employees and myself to make } \\
\text { our company better motivates me }\end{array}$ & $\begin{array}{l}\text { Naplňuje mě motivovat sebe a své } \\
\text { zaměstnance k dalšímu rozvoji naší } \\
\text { společnosti. }\end{array}$ \\
\hline \multirow[t]{2}{*}{ Dev4 } & $\begin{array}{l}\text { Nurturing and growing companies is an } \\
\text { important part of who l am }\end{array}$ & $\begin{array}{l}\text { Rozvoj a expanze společností je důležitou } \\
\text { součástí toho, kým jsem. }\end{array}$ \\
\hline & $\begin{array}{l}1=\text { 'strongly disagree'; } 2={ }^{\prime} \text { disagree'; } \\
3=\text { 'neither agree nor disagree'; } 4=\text { 'agree'; } \\
5=\text { ='strongly agree'. }\end{array}$ & $\begin{array}{l}1 \text { silně (velmi) nesouhlasím } 2 \text { nesouhlasím } \\
3 \text { ani souhlasím ani nesouhlasím } 4 \\
\text { souhlasím } 5 \text { silně (velmi) souhlasím }\end{array}$ \\
\hline
\end{tabular}

